In view of the importance which precise determinations of three-dimensional structures of proteins, nucleic acids and viruses have had in these areas, I was rather disappointed by the discussion of these structures. Certainly, it is difficult to convey the three-dimensional character of these structures in a diagram or photograph, but I had hoped to see more of the basic principles of their design stated. For example, there is no explicit statomont that it is the amino-acid sequence in a protein which in a given environment determines its three-dimensional structure, and the basic principles of the construction of simple viruses from identical protein subunits is inadequately presented. This is a great pity, because the clegance of these solutions to the problems of efficient design makes a ready appeal to the lay audience.

My most serious criticism concerns the plates and figures. Magnificent though many of these arc, a numbor of the figures suffor from minor errors which more careful supervision of the artist would have avoided. Also, it is not always clear which caption refers to which illustration.

I suppose the question this review has to answer is whether I would choose this book if I had six guineas to spend on a Christmas present book for a sixteen year old niece or nephew. I think the answer is yes; in spite of tho fact that it is expensive and there are featurns which could be improved, it is an exciting and stimulating book covering a wide range of topics in medicine and biology.

$$
\text { W. FULLER }
$$

\section{AMINES ACTIVE IN MAN}

\section{Biologically Active Amines found in Man}

Their Biochemistry, Pharmacology and Pathophysiological Importance. By Franz Franzen and Kurt Evsell. Pp. vii +244 . (Pergamon: Oxford, London and New York, Octobcr 1969.) 100s; $\$ 13.30$.

Is 1951, when I was a rosearch student, Guggenheim produced his book The Biogenic Amines which I read with interest and enjoyment. When I was asked to review this book, therefore, I looked forward to the task because I felt that an up-dating of Guggenheim was long orcrdue. Indeed, the authors refer to the considerable increase in knowledge since his time, and so it is all tho more regrettable that this book includes very little of this knowledge. To say that the book is out of date is of little help, so I will let it speak for itself. Of 1,900 references, which make up seventy-five pages, less than 5 por cent can be post-1964. The latest reference to dimothoxyphenylethylamine, which has been discussed many times by different workers, is that of Friedhoff and van Winkle (1962), who considered that "any conclusions based on this result (of DMPE in schizophrenie urine) would be premature". The authors can be the only people so unaware of the current situation.

The monoamine oxidasos are very well revicwed up to about 1945, after which time an evor diminishing amount of work seems to have been done on them so that by about 1962 all work on the subject seems to have ceased. $\mathrm{MAO}$ inhibitors are not mentioned in the brief index but an italicized sentence in the text refers to "compounds alien to the body which are able to inhibit the amine oxidases". Again, it would be assumed from this book that all workers lost interest in these compounds in the carly sixties as no work has been reported since. Of course, it could be claimed that these synthetic compounds are outside the scope of this book, but then, why quote somo forty historical references to the subject?

Of the 244 pages in the book, only 128 are devoted to a discussion of the subject and from this figure must be deducted some 37 pages devoted to one table. The book can therefore be highly recommended to all those who want but a bricf historical review.

IVOR SMITH

\section{WORKSHOP IN PRINT}

Metabolic Effects of Gonadal Hormones and Contraceptive Steroids

Edited by Hilton A. Salhanick, David M. Kipnis and Raymond L. Vande Wiele. (Based on a Workshop held in Boston, Massachusetts, December 1-5, 1968.) Pp. xxix +762. (Plenum Press: New York and London, 1969.) $\$ 27.50$.

WHEN I read a book like this I wonder whether people are starting to forget that journals exist. This book is typical of many that are now appearing. It consists of papers delivered at a workshop conference, allegedly edited, though as almost all of the discussions on the papers are not included, the editing presumably consisted largely of selecting the sequence of the papers and writing tho not very enlightening preface.

As a book, the volume is a very slow starter. The first twenty-nine pages are devoted to telling the reader several times that the contents are based on papers read at a Workshop meeting held in Boston, Massachusetts, December 1-5, 1968; a foreword, a prefacc, a contents, a list of participants, a list of observers, and an introductory note. None of this is of any great interest and it consequently comes as something of a surprise to read on page 731 that the editors selected only very brief sections of discussion to include on the grounds of economy of spaco.

The great bulk of the book consists of fifty-two papcrs that the editor's have (somewhat arbitrarily) divided into the following sections: liver and gastrointestinal tracts (eight papers), carbohydrate metabolism (six), lipid metabolism (six), protein and amino-acid metabolism (six), respiration (two), hypertension and clectrolytes (seven), calcium and skeleton (five), vascular system (scven), contral nervous system (five). The papers are a mixture of studies with oral contraceptives, and with individual sex hormonos, both natural and synthetic. In my opinion, it would have been bettor to have separated these two topics and produced two volumes, one on the metabolic effects of oral contraceptives and the other on sex hormones.

Both the standard of presentation and type of content of the various papers vary enormously. Some are written in the traditional journal style and present the results of original experiments, others recapitulate or cnlarge on data published elsewhere. Still others are reviews of the literature. 'There is a quite considerable overlap of data between certain chapters. This would be unimportant, if the papers were in a journal, but should have been edited out of the book. Many of the individual chapters, considered in isolation, are excellent. There is, for: example, a good review by D. P. Rose of hormone effects on tryptophan motabolism, while R. H. Furman has ably presented the extremely complex problem of steroid effects on serum lipids. The inclusion of some papers in this volume seems rather eurious. There are papers by R. Doll and M. Vessey and by D. G. Seigel and R. E. Markush on the epidemiology of vascular disorders. Both are good, interesting papers, but are not studies on metabolic effects and should not havo been published. in this book.

The lay-out of the book is unusual and erratic. The type varies considerably and is that of standard typewriters so that the book looks more like a collection of manuscripts than a finished work. There is a subject index and a list of drugs citcd in the text. In this list on page 741 the progestogen components of Norlestrin and Norlutate are wrongly given.

I think that the editors of this book have missed a wonderful opportunity. They could have put together a series of tightly edited papers from leading workers in this field to produce a much-needed volume. Instead. they have produced a sloppy, rambling book that is diffcult to use and will soon be forgotten. M. H. Brigas 